\title{
Institutional vacuums in Canadian forest policy: Can criteria and indicators and certification of sustainable forest management fill the void?
}

\author{
by M.K. (Marty) Luckert ${ }^{1,2}$ and Peter C. Boxall ${ }^{1}$
}

\begin{abstract}
This paper discusses the potential of certification and criteria and indicators (C\&I) of sustainable forest management (SFM) for filling voids in forest policy in Canada. These processes have promised advances towards SFM that the current property rights conveyed on the forest industry, through existing systems of tenures, may simply not allow. In general, the broad social welfare approach that current thinking in sustainable development supports, and that certification and criteria and indicators appear to employ, is not consistent with the incentives, rights, and responsibilities that private forestry firms currently hold. There is a fundamental mismatch between the property rights that have been conveyed to private firms operating on public forest lands and what the policy frameworks of certification and C\&I are expected to deliver. The conclusion is that if the voids in forest policy are to be successfully filled by certification and C\&I, the underlying property rights currently held by firms will need revision.
\end{abstract}

Key words: sustainable forest management, criteria and indicators, certification, Canadian forest policy, forest tenures

\section{RÉSUMÉ}

Cet article discute de la possibilité d'utiliser la certification et les critères et indicateurs (C\&I) de l'aménagement forestier durable (AFD) pour remplir les espaces incomplets des textes des politiques forestières au Canada. Ces processus ont permis d'enregistrer des progrès en matière d'AFD que les droits de propriété actuels accordés à l'industrie forestière par lentremise des systèmes de tenure en place ne pouvaient tout simplement pas permettre. En général, lapproche globale de bien-être social que le courant actuel de pensée en matière de développement durable appuie et que la certification et les critères et indicateurs semblent utiliser, ne se raccorde pas aux incitatifs, aux droits et aux responsabilités que les entreprises forestières privées détiennent présentement. Il existe une divergence fondamentale entre les droits de propriétés qui ont été accordés aux entreprises privées en activité sur le territoire forestier public et ce que le cadre de référence des politiques de certification et des C\&I devrait permettre. La conclusion est quadvenant que les espaces incomplets des politiques forestières puissent être complétés avec succès par la certification et les C\&I, les droits de propriété sous-jacents présentement détenus par les entreprises devront être révisés.

Mots clés : aménagement forestier durable, critères et indicateurs, certification, politiques forestières canadiennes, tenures forestières

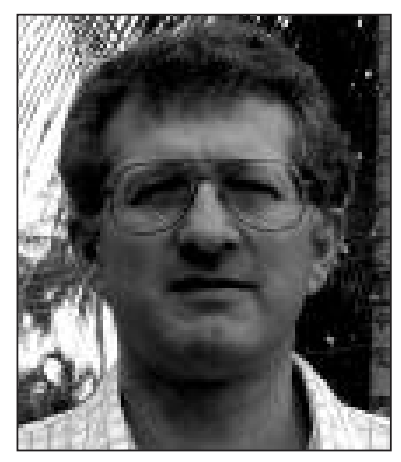

M.K. (Marty) Luckert

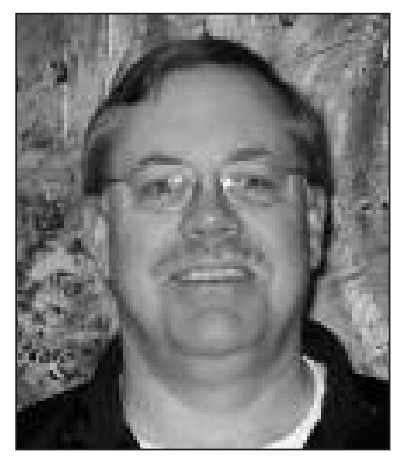

Peter C. Boxall

\section{Introduction}

Vacuums cannot persist because they tend to be filled. If a vacuum begins to emerge, dynamic processes of systems search for disequilibria associated with voids and seek to reestablish equilibrium by filling in gaps. Nature tends to abhor vacuums so strongly that, "The old notion of a complete void, of empty space, is colossally wrong” (Luminet 2002). In this paper we use the notion of vacuums to characterize and assess recent changes in forest policy environments. We maintain that just as vacuums are abhorred in nature, vacuums in public policy can be abhorred by public interests and policy-making processes. In this paper, we use concepts of policy voids to examine recent changes in forest policy and to identify potential problems that these changes have created.

\footnotetext{
${ }^{1}$ Department of Rural Economy, University of Alberta, Edmonton, Alberta.

${ }^{2}$ Corresponding author. E-mail: Marty.Luckert@afhe.ualberta.ca
} 
Public perceptions of forest policy are changing rapidly such that a new paradigm, sustainable forest management (SFM), is replacing the older concepts of sustained yield and multiple use (e.g., Burton et. al 2003). As societal values have changed, perceived vacuums have appeared within sustained yield policies. These voids have attracted policy processes that attempt to fill in the gaps with new, developing forest management concepts (Fraser 2007). Many of these new concepts have their roots in the general concepts of sustainable development originating from the Brundtland Commission (World Commission on Environment and Development 1987). These concepts underpin current discussion of SFM and are founded on the simultaneous consideration of environmental, economic and social dimensions of forests and their management.

Filling the policy voids associated with sustained yield policies has required the practical application of these 3 dimensions of sustainable development. In pursing these concepts within the realm of SFM, 2 basic questions are being pursued: 1) what specifically is sustainable forest management; and 2) how do we measure progress towards achieving sustainable forest management? Both of these questions are being addressed by 2 parallel but interdependent processes. These are criteria and indicators (C\&I) processes, which are driven largely by governments, and forest certification, which has been driven largely by environmental non-governmental organizations (ENGOs). For example, in Canada, the Canadian Council of Forest Ministers ${ }^{3}$ (CCFM) engaged in a collective process that initially established a chosen list of C\&I (CCFM 1996), which has been evolving over time (CCFM 2003). Similarly, an ENGO called the Forest Stewardship Council $^{4}$ (FSC), developed and has continually refined a set of standards for forest certification. Both C\&I and forest certification processes are now so pervasive that they are increasingly being seen as critical foundations for modern forest management in Canada. ${ }^{5}$

Historically, policies governing industrial forestry on public lands, and in some cases private lands, has largely emanated from governments. However, the new policy mechanism of forest certification represents a marked shift in that certification evolved as an "end-run" around government policies. Despite historical lobbying efforts with governments, ENGOs were dissatisfied with government forest policies that influence what takes place on public forest lands. As international governmental processes began to emerge for developing C\&I, ENGOs were embarking on a similar but separate strategy of certification. Essentially, ENGOs perceived a void in government policies and embarked on an attempt to fill this void by harnessing the purchasing powers of consumers who value SFM (Cashore et al. 2003).

\footnotetext{
${ }^{3}$ The CCFM is a body comprised of the 14 federal, provincial and territorial ministers responsible for the management of public forests in Canada. The members are all elected officials.

${ }^{4} \mathrm{FSC}$ was founded in 1996 and is an international, membershipbased, non-profit organization that supports environmentally appropriate, socially beneficial, and economically viable management of the world's forests.

${ }^{5}$ As criteria and indicators and certification has arisen in the context of public forest policies, issues regarding the streamlining of information, planning and reporting for SFM have arisen (Innes et al. 2004, Niemann and Innes 2004). Such considerations are beyond the scope of this paper.
}

The purpose of this paper is to explore a set of problems that may arise as C\&I and certification are pursued to fill the policy voids that society perceives. ${ }^{6}$ Although numerous potential problems regarding C\&I and certification have been previously discussed (Haener and Luckert 1998), the focus in this paper is how existing property right arrangements in forest management can impede the ability of C\&I and certification to further SFM. The case of Canadian forest tenures ${ }^{7}$ will be adopted here, although many of the issues discussed below have applicability in other jurisdictions.

We begin in the next section by defining some key concepts used in this paper: institutions, property rights, and social and public choice aspects of policy. Next, we describe how voids in forest policy processes and results began to form and how C\&I and certification evolved to attempt to fill these voids. We then turn to discussing a number of problems that have arisen as these new policy mechanisms formed to fill the policy voids. We conclude by considering alternative assignments of responsibilities for forest management between private firms, government and society at large.

\section{Definitions of Institutions, Property Rights, and Social and Public Choice Aspects of Policy}

A number of key terms are useful in describing and analyzing the current policy landscape. Because these terms have different meanings in different contexts, we begin with a series of definitions that we will use in this paper.

Cortner et al. (1998) review concepts of institutions from a sociological perspective and refer to them as, "...expressions and mechanisms of collective experiences." Such breadth in this concept of institutions captures a great many different kinds of rules, processes and organizations. However, economists favour a much narrower view of institutions. The economic definition of institutions largely rose from the work by North (1990) who defined institutions as: "the humanly devised constraints that structure political, economic and social interaction." Contrary to sociological concepts of institutions, North (1993) distinguishes this definition clearly from the concept of organizations as institutions: "Institutions are the rules of the game....Organizations are the players..." For our purposes, we adopt North's economic definition of institutions so that we can clearly distinguish rules from organizations.

Property rights are claims to streams of benefits from resources that arise within the context of institutional rules that are frequently established by governments. ${ }^{8}$ The structure of these institutional rules is crucial in establishing incentives associated with property rights and thus can induce the holders of rights to manage resources to influence the flow of benefits which those rights confer. For example, property rights that do not have rules that afford exclusive access to benefit

\footnotetext{
${ }^{6}$ Note that it is not our purpose to attempt to present empirical evidence regarding the actual performance of these policies. Performance is bound to vary greatly among regions, and is difficult to interpret with varying values underlying concepts of SFM. Instead, we concentrate in this paper on identifying potential incongruences between concurrent policy structures that could impede the effectiveness of policies.

${ }^{7}$ In Canada, the vast majority of forests are publicly owned, yet forest harvesting and management is largely undertaken by private firms under agreements known as forest tenures.

${ }^{8}$ Haley and Luckert (1990) provide a review of property right definitions.
} 
streams may reduce incentives to invest in resource conservation (e.g., Cheung 1970). In the context of forest management, variations in property rights may be associated with varying rule structures. These structures are frequently referred to as alternative forms of forest tenure or forest concessions.

In speaking of institutions as rules, there are 2 subsets of rules that may be considered. First, there are rules regarding processes for making further rules. For example, in Canada, some rules of process involve legislative procedures that enact legal efforts in the form of forestry acts. Other rules of process are adopted by forest management agencies, industry and NGOs as part of certification and criteria and indicator policies. Such rules are sometimes referred to as "collectivechoice" and "constitutional-choice rules" (Clogg et al. 2004). Assessing these rules of process is referred to as "public choice" policy analysis by Sen (1995). Second, there is a "lower" set of policy rules that result from these rules of process. For example, many forest policy processes result in specific tenure requirements regarding forest harvesting and regeneration that make up part of the property right structure of forest tenure holders in Canada (e.g., Haley and Luckert 1990). These rules form the basis of property rights that influence the incentives that forestry firms have and the way in which forestry activities are undertaken. These rules, that dictate performance in the woods, are sometimes referred to as "operational rules" in the academic literature (Clogg et al. 2004). Assessing the policy rules that result from policy processes is referred to by Sen (1995) as "social choice" policy analysis.

In the following sections, we use the above-defined concepts of institutions, property rights, and public and social choice analysis to investigate processes that have created policy vacuums and policy responses. As we describe the vacuums that have appeared, we use concepts of public and social choice analysis to consider policy processes and operational rules that arose. These rules form the context within which property rights to forest resources are realized, and influence the incentives that forestry firms have in pursuing SFM. Using these concepts we are able to identify potential mismatches between policy objectives of forest certification and C\&I. These misalignments can provide direction for synchronizing rights of forest tenures with the objectives of SFM.

\section{Policy Voids in Canadian Forest Tenures and the Rise of Certification and C\&I}

There are a number of pervasive institutional characteristics of forest tenures across Canada that may have caused policy voids and the subsequent rise of forest certification and C\&I to fill these voids. These voids may be categorized in terms of public choice (i.e., process) vacuums and social choice (i.e., results) vacuums. As a reflection of these 2 types of voids, certification and C\&I have been characterized as systems-based, performance-based or both. Systems-based schemes assess the processes of forest management planning (i.e., public choice aspects) while performance-based schemes essentially assess outcomes or the results of forest management (i.e., social choice aspects). We address each of these voids in detail below.

Public choice policy voids and changes in systems-based policies Howlett and Rayner (1995) characterize Canadian forest policy formation within an advocacy coalition framework in which governments and industry have historically been close partners in making forest policy. A related view of this situation is one of an "iron triangle," which refers to policy formation arising from tightly knit groups of elected officials, special interest groups and specific bureaucratic agencies (e.g., Berry 1990). These processes of policy formation can be a concern because policy alternatives, or new ideas that challenge the established interests of members of the triangle, may never receive consideration. This "closed" system has the potential to foment social unrest. Pratt and Urquhart (1994) provide an example of this by arguing that during the 1980s, much of the public forest land in Alberta was virtually given away within closed-door deals between government and industry. With forest policies driven by a closed industry and government relationship, Howlett and Rayner (1995) argue that Canadian forest policy was largely stagnant, which created an environment of social unease.

During the early 1990s, this unrest found a pressure release in forest certification. Canadian ENGOs, who were unsatisfied with the historical impact that they were having on government forest policy, discovered the potential power of consumer demands for filling policy voids (Fraser 2007). This led them to embrace Forest Stewardship Council certification as a means of influencing forest practices (Cashore et al. 2003). With the potential power of consumer concerns behind them, ENGOs secured a stronger bargaining stance in processes that began to have greater power for influencing forest practices.

Meanwhile, government C\&I processes were also developing in response to policy voids. Increased public participation began to emerge as a cornerstone of SFM (Adamowicz and Veeman 1998) and was also being integrated into lists of various government standards. Moreover, some provinces started to require formal elements of public participation in their forest tenure agreements. For example, under the new Alberta ground rules the scope for public participation has been expanded, using the detailed description of public participation requirements in the Canadian Standards Association (CSA) ${ }^{9}$ certification standard (ASRD 2006).

In short, the advocacy coalition model, dominated by industry and government, has become unravelled in Canada. The historic void of insufficient public participation is becoming filled as forest certification and C\&I formally advance principles of public participation onto the SFM agenda. With these new policy-making processes developing, we also see results of those processes emerge.

\section{Social choice policy voids and changes to performance-based policies}

Tenure policies in Canada have long been dominated by concepts of sustained yield (Luckert 1997). This pervasive model for forest management resulted in forest management practices on public lands that concentrated on perpetuating evenflow timber volumes. The underlying assumption was that management practices that perpetuated timber flows would also perpetuate all other forest resources, as well as maintain a flow of economic benefits to industry, communities and

\footnotetext{
${ }^{9} \mathrm{CSA}$ is an organization that worked with a diverse range of stakeholders to develop standards for Sustainable Forest Management, see: http://www.csa-international.org/product_areas/forest_products_marking/Default.asp?language=english .
} 
government. But these contentions have long been disputed in the academic literature, particularly by forest economists. ${ }^{10}$ More recently, some segments of the public have also begun to disagree. For example, timber harvesting and regeneration practices are sometimes perceived to have negative effects on non-timber resources (e.g., May 1998).

In the face of increasing social concerns for non-timber resources, timber harvesting and regeneration operations have been subjected to numerous rules, or commands, that specify what may not and must be done. Numerous controls were adopted in an attempt to ensure that these commands were followed. For example, British Columbia adopted the BC forest practices code in 1995, which specified a comprehensive command and control system for forest management.

Within this existing Canadian policy framework of rules, tenure holders have a narrow set of property rights to forest resources that consist largely of timber harvesting. These harvesting rights are exercised within the context of numerous rules that take the form of requirements constraining harvesting in the name of protecting non-timber values. Luckert and Haley (1989) point out that this difference between rights and requirements creates a schism between what forest companies have incentives to do, and what the public thinks forest companies should do. Luckert and Haley (1989) write:

"Individual citizens or groups might, and frequently do, contend that private firms have a moral responsibility to society, both present and future, to .... manage the public forest under their temporary control in a socially desirable manner. However, forest tenure holders cannot be expected to make decisions affecting their own welfare according to what they perceive as being appropriate for society. It is no more reasonable to expect private firms to be motivated by the public interest, as far as land management is concerned, than it is to expect them or any other individual or group for that matter, to voluntarily pay income tax or any other levy to the government."

Based on the principles in this quote it is evident that a policy void has been created by the divergence between private and societal interests in the management of Canadian public forests.

Public unrest regarding the absence of specific and appropriate rules for protecting non-timber values during timber harvesting led to alternative strategies to fill this social choice policy void. The focus of forest policy on timber volumes was no longer sufficient for Canadians who were demanding more from their forests than sustained fibre production. Therefore, SFM arose with some key differences to SY (Luckert 1997, Adamowicz and Veeman 1998). First, SFM explicitly considers values of a broader range of forest goods and services than does SY, including social, cultural and economic values. Second, by considering more than one forest output (i.e., timber volume), trade-offs between different types of competing forest goods, services, uses and managed forest states may be considered. For example, decisions have been made to set aside protected areas and parks in forested areas in a number of Canadian provinces such as has been done through the Ontario Living Legacy policy. These additions to protected

\footnotetext{
${ }^{10}$ For a review of economic critiques of sustained yield, see Luckert
} and Williamson (2005). area systems resulted from considerations of trade-offs between groups of stakeholders, some interested in flows of harvested timber, while others were interested in values associated with preservation. Third, SFM emphasizes key goals of maintaining the health, integrity and biodiversity of forest ecosystems at multiple scales.

With a pervasive, if not always clear, social desire to change from historic SY towards desired SFM policies, a subsequent step was to identify how to change forest management to align it with the new SFM objectives. One of the key processes adopted was to more clearly articulate definitions of SFM in terms of C\&I (CCFM 1996). Similarly, certification systems adopted similar standards that are used to base audits of performance. The logic was, and is, that policy-makers and forest managers need to clearly define SFM with specific benchmarks so that society can gauge the performance of forest management over time. As SFM was defined, expectations emerged regarding industrial performance towards these benchmarks. However, as will be discussed below, the ability of industry to deliver in response to these expectations may be over-estimated.

\section{Problems with C\&l and Certification in Attempting to Fill Policy Voids}

As discussed above, C\&I largely evolved as a process for identifying, pursuing and measuring progress towards SFM. As policy voids spurred on the development of these mechanisms, a number of associated problems surfaced. We refer to these issues as: a) the notion of certification as requirements and responsibilities as opposed to rights and objectives; b) the problem of the accounting stance taken; and c) the fact that "one size doesn't fit all."

Requirements and responsibilities versus rights and objectives The fundamental extent to which C\&I and certification will successfully fill policy voids is largely dependent upon the property rights held by private forestry firms. As mentioned above, rights of forest tenure holders in Canada are largely restricted to timber harvesting. As such, it makes perfect sense for companies to have incentives to create and monitor standards related to timber supply. However, tenure holders do not generally have rights to non-timber resources, and thus standards associated with these elements of forest ecosystems are likely to not be voluntarily pursued unless demanded by consumers through certification or other market means.

To illustrate this point, assume that contrary to most forest tenures in Canada, a forest company was also granted rights to manage for forest recreation on public land. These rights would imply that the company could receive economic benefits from managing forest recreation; perhaps from leasing fishing and/or hunting rights in return for recreation management expenses. In such a scenario the company may have incentives to adjust timber harvesting practices to develop or use existing SFM standards regarding targets for recreational user days provided. However, now assume that the tenure holder does not possess rights to recreation management. That is, their property rights are such that they do not have access to the benefits that recreational forest resources could provide. In such a case, benefits from recreation management are exter- 
nal to the forest company and they do not have the necessary economic incentives to voluntarily set objectives regarding this service that flows from the forest that they influence.

If rights to non-timber resources are not formally granted, there are other possible avenues where incentives to establish standards associated with these resources may arise. For example, forest companies may consider non-timber resources in timber harvest planning so that their products may appear to be "green" to consumers. The prospect of green premiums and/or maintaining existing markets are some of the mechanisms that currently exist to encourage forestry firms to become certified. Similarly, companies may pursue non-timber goals under the concept of corporate social responsibility. This sense of responsibility could be motivated by altruistic motives. However, such motives may be difficult to distinguish from public relations efforts designed to pursue long-term profitability. Since tenure holders operate on public lands, they are reliant on maintaining or increasing public support for their practices as a necessary condition of maintaining their licenses to operate.

Note that motivations from the pursuit of "green" products and/or corporate social responsibility are likely to differ markedly from the case where forest companies would have the rights to non-timber resources and manage these explicitly to produce future benefit streams from these resources. If a company has property rights to non-timber values, then the potential benefit streams from such resources are the source of incentives for management actions. If a firm does not have rights to non-timber values, and actions are being driven by other forces, then potential future benefits are external to the firm and the costs of such actions are borne simply to maintain benefits streams to resources for which rights have already been granted-the harvesting of timber. That is, the benefit stream regarding the management of non-timber forest resources may be dictated by the benefits streams arising from harvesting trees. Returning to the example of rights to forest recreation, if private firms only have timber harvesting rights, then any recreational user days that they choose to supply are likely to be motivated by concerns for keeping or enhancing revenues flowing from timber. Under such conditions, concerns over non-timber resources are likely to take a back seat to the rights to timber harvesting that have been granted.

\section{The accounting stance}

One way of thinking about the potential differences between private and public perspectives is with the concept of an "accounting stance." An accounting stance establishes specifically what benefits and costs would be considered part of an analysis. The previous discussion suggests that rights granted to forestry firms are crucial in defining what they think an appropriate accounting stance should be. Given that industry is granted rights to timber, but that society has a wider set of interests, the accounting stance adopted by industry is likely to be different from the stance that society would adopt. Moreover, there are also difficulties in defining a social accounting stance. Elements of social values include values held by ENGOs and other community groups. All of these entities hold subsets of social values that result in accounting stances that are likely to be only pieces of the complete social accounting stance that we would want land managers to use in managing a public resource on behalf of society in general. In sum, forest management standards in Canada are being developed in a policy environment with numerous accounting stances that may conflict, or when taken together, may not reflect the larger set of relevant social values.

Differences in perspectives and accounting stances among different groups have the potential to create schisms between groups trying to construct C\&I (Jeakins 2004). For example, economists-attempting to take an overarching social welfare approach-highlight the importance of understanding the role of forest harvesting within the context of non-timber values and wider societal concerns regarding distributions within and between members of current and future generations (e.g., Adamowicz 2003). They also point out the importance of understanding how forest harvesting may impact community and regional sustainability. Forest companies, with limited existing property rights, look at the breadth of C\&I that economists propose and voice considerable concerns, albeit to varying degrees based on their perceived corporate social responsibilities. These companies enter into certification and C\&I processes where they are bombarded with constant pressure from groups to continually widen their accounting stance to include economic and social concerns, even beyond the forestry sector, that encompass such indicators as local unemployment levels, spousal abuse and alcoholism. Within this context a key challenge lies in making a "business case" for incorporating C\&I into the day to day activities of forestry firms (Jeakins 2006).

In a policy context where forest companies have narrow accounting stances dictated by limited property rights, consideration of non-timber values and other broader social concerns typically emerge as constraints on timber harvesting rights. Within this context, a number of issues associated with the specificity of forest management standards can arise.

\section{One size doesn't fit all}

Forests display a vast array of ecological and social conditions. Yet national and international certification and C\&I programmes seek to establish processes and standards that are applicable across jurisdictions. Given difference in local situations, it can be difficult, if not impossible, to establish a universal set of standards that are relevant across forests throughout Canada, or even the world. As C\&I and certification have been implemented, 2 basic approaches for dealing with this challenge have emerged. The first involves varying the degree of specificity of the criteria and indicators. The second involves the development of the criteria and indicators primarily by individuals or organizations who reside in or near the forest of concern. Each of these approaches is discussed in turn below.

\section{Varying the specificity of C\&I and certification standards}

The first approach for addressing the "one size doesn't fit all" problem is based on social choice concepts of adjusting the C\&I and certification policy results or "operational rules." Recognizing problems with specific universal standards, the concept here is that it may be possible to specify general objectives for a firm to pursue rather than prescribing exactly what a firm must do. Historically, many regulatory commands and controls have been quite prescriptive, specifying for example the numbers of stems per hectare that must be 
regenerated. The $\mathrm{BC}$ forest practices code, referred to above, is a classic example. When it was first introduced, this code required numerous specific practices for specified conditions. However, given the regulatory burden caused by this approach, British Columbia and other provinces have recently entertained alternative approaches referred to as "results-based" management. Such an approach would allow firms to pursue a number of different options that could vary within specific contexts. Thus, for example, instead of specifying numbers of stems per hectare to be planted, the resultsbased approach may require the maintenance of a specified annual allowable cut over time, which may indirectly require an implied level of reforestation. This approach also allows the firm the freedom to innovate in pursuing this objective. Note that while both of these approaches are still likely to contain elements of commands and controls, the key difference is in the level of the objective to which the command pertains. Results-based strategies have commands that represent higherorder objectives than are found in prescriptive policies.

Given that results-based policies are based on higherorder commands that provide more flexibility than lowerorder prescriptive commands, we would expect to see differing responses by forestry companies to these 2 types of commands and therefore different outcomes. In cases with more prescriptive policies, companies may have fewer opportunities to be innovative since there are not as many paths available in pursuing lower level objectives as there are in pursuing higher-order objectives. Furthermore, results-based policies require that links between intermediate steps and higher-order objectives are explicitly considered, whereas more prescriptive policies may never be linked to higherorder objectives.

Although results-based approaches are likely to provide more flexibility to forest companies and make more explicit the links to higher-order objectives than more prescriptive approaches, they are not without problems. With more flexibility in the commands comes increased complexity in the controls. With a prescriptive command, such as number of stems per hectare, it is quite straightforward, although expensive, to monitor whether the command has been met. However, with more general objectives, such as maintaining an allowable annual cut, there are many areas of uncertainty and accompanying assumptions that make it unclear whether a company is meeting the criteria. ${ }^{11}$ Furthermore, making objectives more general does not ensure that they will be appropriate across multiple sites.

\section{Local determination of $\mathbf{C \& I}$ and certification standards}

A second approach for addressing the "one size doesn't fit all" problem is based on the public choice concept of policy

\footnotetext{
${ }^{11}$ The above discussion on tradeoffs associated with more and less prescriptive C\&I parallels debates within the economic sustainability literature. Much like prescriptive C\&I, "strong sustainability" policies tend to require the sustainability of individual elements of systems and can lead to more prescriptive policies. In contrast, much like management by objective C\&I, "weak sustainability" policies concentrate on what the economic system as a whole may produce and can lead to policies that allow firms more paths in the pursuit of higher-order objectives. For more in depth discussions of strong and weak sustainability concepts and forest policies, see Luckert and Williamson (2005).
}

processes. That is, instead of trying to specify a command that is applicable over a number of scales, local processes could be relied upon to specify what local standards should be. In these cases, public choice standards tend to specify systems that are thought to be necessary to develop social choice standards needed to dictate forest management results.

Although devolving more responsibility to local authority may improve the relevance of social choice standards for matching local circumstances, there may be problems. One such problem arises because many concerns of stakeholders may not be locally based. Values of urban populations, spatially remote from forests, are becoming increasingly important in forest management (Luckert 1997). Moreover, there are also issues associated with how specific to make the public choice standards regarding local processes. Just as too much specificity can lead to inappropriate social choice standards for assessing results of forest management, so can too much specificity lead to inappropriate public choice standards for guiding public processes. Accordingly, these processes may remain too general.

This generality can result in problems. If problems of "one size doesn't fit all" push social and public choice standards to highly general levels, then the end result can be that the policy void is being filled with such a generalized C\&I and/or certification policies, that firms may be doing little, if anything, more than what they were doing before the standards were introduced. In such cases the adoption of "new" certification and C\&I could result in minimal changes in forest management practices (Haener and Luckert 1998).

\section{Discussion and Conclusions}

The discussion above describes how policy voids in forestry emerged in Canada and how certification and C\&I emerged to attempt to fill these voids. But to what extent have these new policies been successful, and how successful are they likely to be? In other words, to what extent have the voids been effectively filled?

Responses to these types of questions are inherently subject to conjecture, as measuring improvements in forest practices relative to social concepts such as SFM are likely to vary significantly with specific ecological and social settings. We are therefore forced towards employing limited empirical experiences, sometimes less charitably referred to as anecdotes, informed by our analyses of current policy frameworks and the situations that these frameworks have created.

Policy voids may be viewed differently depending on whether they are considered public choice voids or social choice voids. With respect to public choice voids, we believe that few would argue that there have not been marked improvements in policy processes that have effectively filled vacuums as a result of certification and C\&I. These 2 processes have made significant inroads into breaking the historic advocacy coalitions between provincial governments and industry. Although the introduction of such processes have not always, or perhaps hardly ever, been easy, they have nonetheless generally increased communication flows and begun to change the stagnant policy environment characteristics of the era of sustained yield management in Canada.

But such processes can only be judged successful if they are evaluated within the context of the quality of the policies that they are creating. That is, if we are to contemplate the successes that C\&I and certification have had in improving 
forest policy processes, it is relevant to consider these policies from a social choice perspective. No matter how inclusive and communicative a process is, it cannot persist if the policies that result are not doing a better job in meeting the range of social expectations regarding SFM. That is, if social choice policy voids have been ineffectively filled, current certification and C\&I processes will be abandoned for alternative future strategies.

So how successfully have social choice voids been filled? The discussion above suggests that there may be some structural problems that limit the ability of certification and C\&I to fill these voids. In a nutshell, the property rights conveyed through Canadian forest tenures are quite narrow, reflecting historic sustained yield policies, yet certification and C\&I mechanisms require much broader rights to pursue the broader concept of SFM. There is a fundamental mismatch between the property rights that we have conveyed to private firms operating on public forest lands and what we expect the policy frameworks of certification and C\&I to deliver.

The policy responses of certification and C\&I have, in some ways, mimicked the historic approaches of trying to accommodate non-timber concerns in forest management. New standards have been developed that sought to expand considerations beyond timber values. But such approaches may have, unwittingly, had the exact opposite effect. Instead of expanding the timber interests of forestry firms to include non-timber values, C\&I and certification have simply added constraints to harvesting activities, further limiting the narrow timber harvesting rights that private firms already possess. These observations are not meant to suggest that it would be better to grant, for example, biodiversity rights to private firms. We cannot expect private interests to look after such social concerns. However, it may be equally erroneous to expect private interests to voluntarily look after such concerns from a broader social accounting stance in a context where their property rights are composed of limited benefit streams to timber resources. What then, can policy makers do?

To begin with, it is useful to think of the standards associated with C\&I and certification as more than definitions and goals for SFM. They are also policy mechanisms that, in conjunction with current forest tenure policies, specify the property rights and accompanying incentives that private firms possess. These incentives limit the ability of industry to respond to SFM objectives, suggesting a potential need to reshuffle the rights and responsibilities of forest management. This process of assigning rights to forest resources involves identifying areas where private and social values may coincide and places where they likely will not. For example, as discussed above, it is unlikely that society can expect private industry to voluntarily provide goods and services such as biodiversity and wilderness, in ways that coincide with social objectives. However, there are other aspects of forest resources where closer scrutiny may divulge more overlap than heretofore thought.

To illustrate this overlap, one of the original concepts associated with private companies operating on Crown lands was to harness the capital and efficiencies of private industry in harvesting and processing wood. This strategy is as relevant now as it was in the past if one sets aside problems of competing non-timber forest resource values. However, current tenure policies not only attenuate property rights for nontimber concerns, they also place restrictions on practices because of concerns about timber values. Increasingly, these types of constraints are appearing misplaced. For example, Luckert and Williamson (2005) summarize arguments that suggest that private interests in sustaining timber supplies may provide for greater community stability and sustainability than publicly controlled sustained yield policies. Moreover, tenure requirements that link wood supplies to processing plants may be impeding value-added manufacturing rather than promoting it. To the extent that these requirements for timber harvesting and processing are misplaced, the values of property rights to the private forestry firms facing these requirements are decreased, thereby leaving less room for industry to deal with non-timber requirements.

But even if timber harvesting and production standards can be realigned in tenure reform, society still has the task of dealing with those forest resource values where social and private interests are not likely to coincide. For such cases it may be necessary to shift responsibility out of private hands. Haley and Luckert (1998), for example, suggest a mechanism whereby the Crown retains an interest in carbon sequestration values, while leaving timber values in private hands. Although a review of different policy options for shifting private and public rights and responsibilities is beyond the scope of this paper, we suggest that such considerations will become increasingly important in balancing expectations with the actual performance of certification and C\&I policies.

Certification and C\&I have made significant progress in filling public choice policy voids. However, if such progress is to be maintained, these policy tools must also deliver on the social choice front. In order for this success to occur, the standards and regulations created by these processes will have to evolve beyond wish lists and commands and controls to consider the underlying structure of rights and responsibilities that the current tenure system creates. Without significant attention to new policies regarding these underlying property rights, the ambitious and far-reaching goals that the pursuit of SFM requires are likely to prove increasingly elusive.

\section{Acknowledgements}

Thanks to John Ward, Jim McColl and Mike Young and 2 anonymous referees for their comments. We also thank Cindy Pearce and Tom Maness for providing the forum in which the opinions expressed in this essay were formed. Funding for this work was provided by the Sustainable Forest Management Network.

\section{References}

Adamowicz, W.L. 2003. Economic indicators of sustainable forest management: Theory versus practice. Journal of Forest Economics 9: $27-40$.

Adamowicz, W. and T. Veeman. 1998. Forestry policy and the environment: Changing paradigms. Canadian Public Policy 24(Supplement 2): S51-S61.

[ASRD] Alberta Sustainable Resource Development. 2006. Alberta Forest Management Planning Standard, Version 4.1. Forest Management Branch, Public Lands and Forests Division, Alberta Sustainable Resource Development, Edmonton, AB.

Berry, J.M. 1990. Subgovernments, issue networks, and political conflict. In R. Harris and S. Kilkis (eds.). Remaking American Politics. pp. 239-269. Westview Press, Boulder, CO.

Burton, P.J., C. Messier, G.F. Weetman, E.E. Prepas, W.L. Adamowicz and R. Tittler. 2003. The current state of boreal forestry and the drive for change. In P.J. Burton, C. Messier, D.W. 
Smith, and W.L. Adamowicz (eds.). Towards Sustainable Management of the Boreal Forest. pp. 1-40. NRC Research Press, Ottawa. [CCFM] Canadian Council of Forest Ministers. 1996. Defining Sustainable Forest Management: A Canadian Approach to Criteria and Indicators. Canadian Forest Service - Natural Resources Canada, Ottawa.

2003. Defining Sustainable Forest Management in Canada: Criteria and Indicators 2003. Canadian Forest Service - Natural Resources Canada, Ottawa.

Cashore, B., G. Auld and D. Newsom. 2003. The United States' race to certify sustainable forestry: non-state environmental governance and the competition for policy-making authority. Business and Politics Vol. 5 Issue 3.

Cheung, S.N.S. 1970. The structure of a contract and the theory of a non-exclusive resource. Journal of Law and Economics 13:49-70.

Clogg, J., G. Hoberg and A. O'Carroll. 2004. Policy and Institutional Analysis for Implementation of the Ecosystem-Based Management Framework. Coast Information Team Victoria, British Columbia. Available at http://www.citbc.org/c-ia-final-06may04.pdf [Accessed on Aug. 18, 2006].

Cortner, H.J., M.G. Wallace, S. Burke and M.A. Moote. 1998. Institutions matter: The need to address the institutional challenges of ecosystem management. Landscape and Urban Planning 40: 159-166.

Fraser, S.J. 2007. Filling a public policy gap in Canada: Forest certification. The Forestry Chronicle 83: 666-671.

Haener, M.K. and M.K. Luckert. 1998. Forest certification: Economic issues and welfare implications. Canadian Public Policy 24: S83-S94.

Haley, D. and M.K. Luckert. 1990. Forestry tenures in Canada: A framework for policy analysis in Canada. Forestry Canada Information Report E-X-43. Supply and Services Canada, Ottawa.

Haley D. and M.K. Luckert. 1998. Tenures as Economic Instruments of Achieving Objectives of Public Forest Policy in British Columbia. In C. Tollefson (ed.). The Wealth of Forests: Markets, Regulation and Sustainable Development. pp. 123-151. UBC Press, Vancouver.

Howlett, M. and J. Rayner. 1995. Do ideas matter? Policy network configurations and resistance to policy change in the Canadian forest sector. Canadian Public Administration 38: 382-410.

Innes, J.L., B. Wilson and G.M. Hickey. 2004. Streamlining planning and reporting for sustainable forest management. In J.L. Innes, G.M. Hickey and B. Wilson (eds.). International perspectives on streamlining local-level information for sustainable forest manage- ment. A selection of papers from a conference held in Vancouver, Canada, August 28 and 29, 2000. Information Report BC-X-400. Natural Resources Canada - Canadian Forest Service, Pacific Forestry Centre, Victoria. 109 p.

Jeakins, P. 2004. Economic Perspectives for Sustainability: A Corporate Approach. Sustainable Forest Management network Tomorrow's Forests Newsletter, Winter 2004 (Web Edition). [online]. Available at http://www.sfmnetwork.ca/html/tf2004winter_e.html. [Accessed on March 30, 2007].

Jeakins, P. 2006. The business of Criteria and Indicators in sustainable forest management. The Forestry Chronicle. 82(3): 412-415.

Luckert, M.K. 1997. Towards a tenure policy framework for sustainable forest management. The Forestry Chronicle. 73(2): 211-215.

Luckert, M.K. and D. Haley. 1989. Forest tenures - requirements, rights and responsibilities: An economic perspective. The Forestry Chronicle. 65(3): 180-182.

Luckert, M.K. and T.B. Williamson. 2005. Should sustained yield be part of sustainable forest management? Canadian Journal of Forestry Research. 35 (2): 356-364.

Luminet, J.P. 2002. Book review: "The Book of Nothing: Vacuums, Voids, and the Latest Ideas About the Origins of the Universe." Notices of the American Mathematical Society 49(6): 676-678.

May, E. 1998. At the Cutting Edge: The Crisis in Canada's Forests. Sierra Club Books. 294 p.

Niemann, T. and J.L. Innes. 2004. Streamlining local-level information for sustainable forest management. In J.L. Innes, G.M. Hickey and B. Wilson (eds.). International perspectives on streamlining local-level information for sustainable forest management. A selection of papers from a conference held in Vancouver, Canada, August 28 and 29, 2000. Information Report BC-X-400. Natural Resources Canada - Canadian Forest Service, Pacific Forestry Centre, Victoria. $109 \mathrm{p}$.

North, D.C. 1990. Institutions, Institutional Change and Economic Performance. Cambridge University Press, Cambridge, UK.

North, D.C. 1993. The new institutional economics and development. Economics Working Paper Archive at WUSTL, Economic History, \#9309002, Washington University. Available at http://econwpa.wustl.edu.

Pratt, L. and I. Urquhart. 1994. The Last Great Forest: Japanese Multinationals and Alberta's Northern Forests. NeWest Publishers, Edmonton.

World Commission on Environment and Development. 1987. Our Common Future. Oxford University Press, Oxford, UK. 